\section{Kidney \\ Blood Pressure Research}

Kidney Blood Press Res 2012;36:355-364

\begin{tabular}{l|l}
\hline DOI: $10.1159 / 000343393$ & C) 2012 S. Karger AG, Basel
\end{tabular}

www.karger.com/kbr

1420-4096/12/0361-0355\$38.00/0

\title{
Enhanced FGF23 Serum Concentrations and Phosphaturia in Gene Targeted Mice Expressing WNK-Resistant Spak
}

\author{
Ganesh Pathare ${ }^{\mathrm{a}}$ Michael Föller ${ }^{\mathrm{a}}$ Diana Michael ${ }^{\mathrm{a}}$ Britta Walker $^{\mathrm{a}}$ \\ Michael Hierlmeier ${ }^{\mathrm{a}} \quad$ Julia G. Mannheim ${ }^{\mathrm{b}}$ Bernd J. Pichler ${ }^{\mathrm{b}}$ Florian Lang ${ }^{\mathrm{a}}$ \\ aDepartment of Physiology, University of Tübingen, Gmelinstr. 5, D-72076 Tübingen, Germany, \\ 'Department of Preclinical Imaging and Radiopharmacy, Eberhard Karls University Tübingen, \\ Röntgenweg 13, D-72076, Tübingen, Germany
}

\section{Key Words}

$\mathrm{pH}_{\mathrm{i}} \cdot \mathrm{Na}^{+} \bullet$ phosphate cotransporter $\bullet \mathrm{FGF} 23 \cdot$ bone density

\begin{abstract}
Background: The WNK-dependent STE20/SPS1-related proline/alanine-rich kinase (SPAK) regulates the renal thiazide sensitive $\mathrm{NaCl}$ cotransporter (NCC) and the renal furosemide sensitive $\mathrm{Na}^{+}, \mathrm{K}^{+}, 2 \mathrm{Cl}^{-}$cotransporter (NKCC2) and thus participates in the regulation of renal salt excretion, extracellular fluid volume and blood pressure. Inhibition of NCC leads to anticalciuria. Moreover, NCC is also expressed in osteoblasts where it is implicated in the regulation of bone mineralization. Osteoblasts further influence mineral metabolism by releasing the phosphaturic hormone FGF23. The present study explored, whether SPAK participates in the regulation of calcium-phosphate homeostasis. Methods: FGF23 serum levels and phosphate homeostasis were analyzed in gene targeted mice expressing SPAK resistant to WNK-dependent activation (spak ${ }^{\mathrm{tg} / \mathrm{tg}}$ ) and in mice expressing wild type SPAK (spak ${ }^{\mathrm{wt} / \mathrm{wt}}$ ). Results: Serum FGF23 level was significantly higher, urinary phosphate excretion significantly larger and serum phosphate concentration significantly lower in spak ${ }^{\mathrm{tg} / \mathrm{tg}}$ mice than in spak ${ }^{\mathrm{wt} /}$ ${ }^{\text {wt }}$ mice. Urinary calcium excretion was significantly decreased in $s p a k^{\text {tg }}{ }^{\text {tg }}$ mice. Serum levels of calcitriol and PTH were not significantly different between the genotypes. Bone density was significantly increased in spak ${ }^{\text {tg/tg }}$ mice compared to spak ${ }^{\mathrm{wt} / \mathrm{wt}}$ mice. Treatment of spak ${ }^{\mathrm{wt} / \mathrm{wt}}$ mice with HCT increased FGF23 serum levels, and led to phosphaturia and hypophosphatemia. Conclusions: SPAK is a strong regulator of FGF23 formation, bone mineralization and renal $\mathrm{Ca}^{2+}$ and phosphate excretion.
\end{abstract}




\section{Kidney \\ Blood Pressure Research}

Kidney Blood Press Res 2012;36:355-364

\begin{tabular}{l|l}
\hline DOI: 10.1159/000343393 & C 2012 S. Karger AG, Basel
\end{tabular}

Published online: December 12, 2012

www.karger.com $/ \mathrm{kbr}$

作öler/Michael/Walker/Hierlmeier/Mannheim/Pichler/Lang: SPAK-Sensitive Phosphaturia

\section{Introduction}

SPAK (SPS1-related proline/alanine-rich kinase) is a key regulator of renal tubular salt transport and blood pressure [1-3]. SPAK is under control of the with-no-K(Lys) (WNK) kinases [1, 4-8], which are similarly decisive for renal salt excretion and blood pressure regulation [7, 9-12]. Mutations within WNK kinases cause Gordon's syndrome, a monogenic disease leading to hypertension and hyperkalaemia $[6,8,13,14]$. SPAK and the related oxidative stress-responsive kinase 1 (OSR1) kinase modify renal salt excretion and blood pressure at least partially through activation of the $\mathrm{NaCl}$ cotransporter (NCC) and the $\mathrm{Na}^{+}, \mathrm{K}^{+}, 2 \mathrm{Cl}^{-}$cotransporter (NKCC2) [4, 5, 7, 15-25].

Inhibition of NCC with thiazides is followed by anticalciuria [26]. Moreover, thiazide sensitive NCC activity is a powerful regulator of bone differentiation and bone mineralisation $[27,28]$. Thus, at least in theory, WNK sensitive regulation of SPAK could participate in the regulation of $\mathrm{Ca}^{2+}$ and phosphate metabolism. As a matter of fact, a WNK4 gene variant has been shown to be associated with osteoporosis [29]. However, nothing is known about a role of SPAK in the regulation of renal tubular transport of $\mathrm{Ca}^{2+}$ and phosphate. Renal phosphate excretion is under regulation by dietary phosphate intake, acid-base status, parathyroid hormone, 1,25- $(\mathrm{OH})_{2}$ vitamin $\mathrm{D}_{3}$, FGF23, insulin and insulin-like growth factor IGF1 [30-36]. Signaling known to regulate renal tubular phosphate transport include protein kinases A and C, ERK1/2, Klotho and the PI3K/PKB/GSK3 kinase cascade [37-44].

The present study addressed the putative role of SPAK in the regulation of renal $\mathrm{Ca}^{2+}$ and phosphate metabolism. To this end, urinary $\mathrm{Ca}^{2+}$ and phosphate output as well as serum $\mathrm{Ca}^{2+}$, phosphate, PTH, $1,25(\mathrm{OH})_{2} \mathrm{D}_{3}$ and FGF23 concentrations were determined in gene targeted mice expressing WNK-resistant SPAK $\left(\operatorname{spak}^{\mathrm{tg} / \mathrm{tg}}\right)$ [1] and in the respective wild type mice $\left(s p a k^{w t / w t}\right)$. The observations point to an effect of SPAK on the regulation of bone mineralization and FGF23 release as well as renal tubular $\mathrm{Ca}^{2+}$ and phosphate transport.

\section{Materials and Methods}

\section{Animals}

All animal experiments were conducted according to the German law for the welfare of animals and were approved by local authorities. Blood was drawn, urine collected or tissue isolated from sex- and agematched 3-8-month-old homozygous SPAK knockin mice $\left(s p a k^{t g / t g}\right)$ and respective wild type mice (spak $\left.{ }^{w t / w t}\right)$, kindly provided by Dario Alessi. As described earlier [1] in the knockin mice the T-loop Thr residue in SPAK (Thr243) was mutated to Ala to prevent activation by WNK isoforms. Mice had free access to control diet (sniff, Soest, Germany) containing $7000 \mathrm{mg} / \mathrm{kg}$ phosphorus or to phosphate-depleted diet (Altromin, Lage, Germany) containing $131 \mathrm{mg} / \mathrm{kg}$ phosphate and to tap drinking water ad libitum. Where indicated, the mice were treated with hydrochlorothiazide (Sigma Aldrich, Germany), which was first dissolved in DMSO and then in drinking water at the dose of $600 \mathrm{mg} / \mathrm{l}$ for 12 days. To obtain serum, mice were anaesthetized with diethylether (Roth, Karlsruhe, Germany) and blood was drawn into capillaries by puncturing the retroorbital plexus.

To determine urinary parameters, the mice were placed individually in metabolic cages (Techniplast, Hohenpeissenberg, Germany) as described previously. They were allowed a 2 day habituation period during which food and water intake, urinary flow rate and phosphate excretion were recorded every day to ascertain that the mice were adapted to the new environment. Subsequently, $24 \mathrm{~h}$ collection of urine was performed for three consecutive days in order to obtain the urinary parameters. This procedure was repeated under low-phosphate diet. To assure quantitative urine collection, metabolic cages were siliconized, and urine was collected under water-saturated oil.

The phosphate concentration was determined colorimetrically utilizing a commercial diagnostic kit (Roche Diagnostics, Mannheim, Germany). ELISA kits were employed for determination of the serum intact parathormone concentration (Immutopics, San Clemante, USA), of $1,25(\mathrm{OH})_{2} \mathrm{D}_{3}$ concentration (IDS Diagnostics, Frankfurt/Main, Germany) and of FGF23 concentration (Immutopics). 


\section{Kidney \\ Blood Pressure Research}

Kidney Blood Press Res 2012;36:355-364

\begin{tabular}{l|l}
\hline DOI: $10.1159 / 000343393$ & C 2012 S. Karger AG, Basel
\end{tabular}

Published online: December 12, 2012

www.karger.com/kbr

Päl/Föller/Michael/Walker/Hierlmeier/Mannheim/Pichler/Lang: SPAK-Sensitive Phosphaturia

Bone density

For the analysis of bone density, animals were sacrificed and legs were amputated and fixated in PFA (paraformaldehyde). The samples were scanned with a high resolution X-ray computed tomography (Inveon SPECT/CT) scanner (Siemens Preclinical Solutions, Knoxville, TN, USA) using a field of view of $3.6 \times 3.6 \times 3,6 \mathrm{~cm}^{3}$. The X-ray tube parameters were set at $80 \mathrm{kVp}$ and $500 \mu \mathrm{A}$. The images were acquired with 400 angular projections (exposure time $1000 \mathrm{~ms}$ per projection) over 200 degree and binned with a factor of two, yielding a reconstructed pixel size of $\sim 35 \mu \mathrm{m}$. The total scan time was 12 minutes. Reconstructed CT images were analyzed with the Inveon Research Workplace software (Siemens Preclinical Solutions, USA), by drawing a standard-sized container around the femur and applying a region growth routine to segment the trabecular bone structure. For all samples, the same upper and lower density threshold was applied and the relative numbers of trabecular bone density compared.

\section{SPAK transcripts in UMR106 cells}

Rat osteosarcoma UMR106 cells $\left(10^{6}\right)$ were cultured in Dulbecco's MEM medium, supplemented with $10 \%$ fetal bovine serum, $1 \mathrm{mM}$ sodium pyruvate, 50 units $/ \mathrm{ml}$ penicillin, and $50 \mu \mathrm{g} / \mathrm{ml}$ streptomycin, at $5 \% \mathrm{CO}_{2}$, and $37^{\circ} \mathrm{C}$ for 2 days. Cells were lysed, total RNA isolated (Mini kit, Qiagen, Hilden, Germany) and $1 \mu \mathrm{g}$ transcribed into cDNA using reverse transcriptase (Roche Diagnostics GmbH, Roche Applied Science, Mannheim Germany). Aliquots of cDNA, corresponding to equal amounts of RNA, were used for quantification of mRNA. Specific primers for rat used were:

Sense primer: AAGTCATGGAACAGGTGAGAGGC

Antisense primer: TTCAGTCTTATGAAGGTGACCGC

The mRNA was subjected to RT-PCR analysis using the light cycler system (Roche Diagnostics GmbH, Roche Applied Science, Mannheim Germany). The reaction mixture of $20 \mu$ l contained cDNA, $10 \mathrm{mM} \mathrm{MgCl}_{2}$, $0.5 \mu \mathrm{M}$ of each primer, and $1 \mu \mathrm{l}$ Master Syber Green I mix (LightCycler ${ }^{\mathrm{TM} F a s t S t a r t ~ M a s t e r ~ S y b e r ~ G r e e n, ~}$ Roche). The transcript level of the housekeeping gene GAPDH of the sample was taken as reference using a commercial primer kit (Search LC, Heidelberg, Germany). Amplification of the target DNA was performed during 35 cycles, each of $10 \mathrm{~s}$ at $95^{\circ} \mathrm{C}, 10 \mathrm{~s}$ at $68^{\circ} \mathrm{C}$ and $16 \mathrm{~s}$ at $72^{\circ} \mathrm{C}$. The product size was analysed on $1.5 \%$ agarose gel.

\section{Statistics}

Data are provided as means \pm SEM, $n$ represents the number of independent experiments. All data were tested for significance using unpaired Student's t-test or ANOVA, as appropriate. Only results with $p<0.05$ were considered statistically significant.

\section{Results}

In order to elucidate, whether phosphate metabolism is sensitive to WNK dependent regulation of SPAK, experiments were performed in SPAK knockin mice ( spak $^{\text {tg/tg }}$ ), which

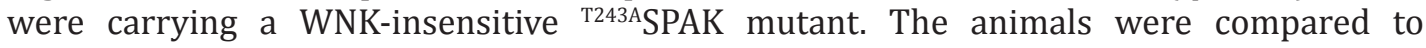
respective wild type mice ( $\left.s p a k^{w t / w t}\right)$. Urinary phosphate excretion was significantly higher in spa $^{\text {tg/tg }}$ mice than in spak ${ }^{\text {wt/wt }}$ mice (Fig. 1). As shown in Fig. 1, a low-phosphate diet decreased the urinary phosphate excretion to similarly low levels in $s p a k^{\text {tg/tg }}$ and $s p a k^{w t / w t}$ mice. In contrast to urinary phosphate excretion, urinary $\mathrm{Ca}^{2+}$ excretion was significantly lower in spak ${ }^{\text {tg/tg }}$ than in spak ${ }^{\text {wt/wt }}$ mice. Low phosphate diet increased urinary $\mathrm{Ca}^{2+}$ excretion in both genotypes. During low phosphate diet urinary $\mathrm{Ca}^{2+}$ excretion was still significantly lower in spak $^{\text {tg/tg }}$ than in spak ${ }^{w t / w t}$ mice.

In theory, the phosphaturia of $s p a k^{\text {tg/tg }}$ mice could have been due to an increased serum phosphate concentration. Conversely, phosphaturia due to decreased renal tubular phosphate transport should result in a decrease of serum phosphate concentration. Thus, serum phosphate concentration was determined. As shown in Fig. 2, the serum phosphate concentration was significantly lower in spak ${ }^{\text {tg/tg }}$ mice than in $s p a k^{w t / w t}$ mice. Thus, the phosphaturia of $s p a k^{t g / t g}$ mice was not due to hyperphosphatemia but obviously resulted in hypophosphatemia. Dietary phosphate depletion decreased the serum phosphate 


\section{Kidney Blood Pressure Research}

Fig. 1. Urinary phosphate and $\mathrm{Ca}^{2+}$ excretion in $s p a k^{w t / w t}$ and spak $^{\text {tg/tg }}$ mice. Arithmetic means \pm SEM $(n=10-12)$ of urinary phosphate $(\mathrm{A})$ and $\mathrm{Ca}^{2+}$ (B) excretion in homozygous SPAK knockin mice (spak ${ }^{\text {tg/tg }}$, black bars) and wild type mice $\left(\right.$ spak $^{w t / w t}$, white bars) under normal diet (left bars) and following dietary phosphate depletion (right bars). * $(\mathrm{p}<0.05)$ indicates significant difference from spak $^{w t / w t}$ mice, \# $(\mathrm{p}<0.05)$ indicates significant difference from control diet.
Pathare/Föller/Michael/Walker/Hierlmeier/Mannheim/Pichler/Lang: SPAK-Sensitive Phosphaturia

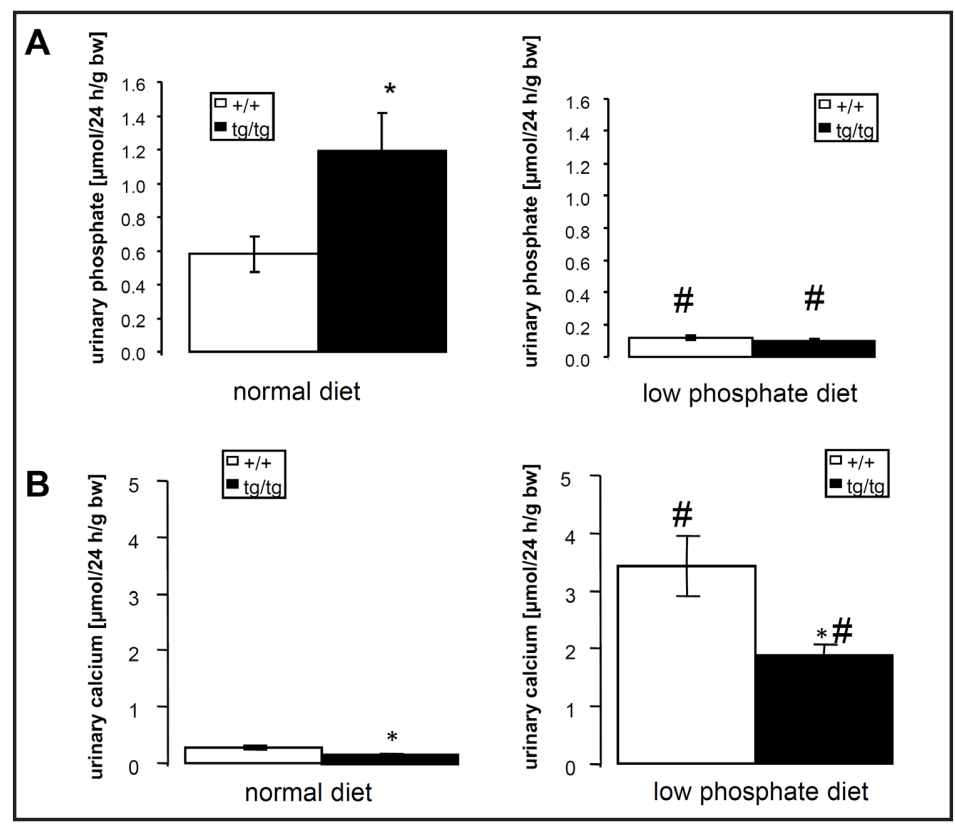

Fig. 2. Serum phosphate and $\mathrm{Ca}^{2+}$ concentrations in spak $^{w t / w t}$ and spak $^{\text {tg/tg }}$ mice. Arithmetic means \pm SEM (n $=10-12$ ) of serum phosphate (A) and $\mathrm{Ca}^{2+}$ (B) concentration in homozygous SPAK knockin mice (spak ${ }^{t g / t g}$, black bars) and wild type mice $\left(s p a k^{w t / w t}\right.$, white bars) under normal diet (left bars) and following dietary phosphate depletion (right bars). * $(\mathrm{p}<0.05)$ indicates significant difference from spak $k^{w t / w t}$ mice, \# $(\mathrm{p}<0.05)$ indicate significant difference from control diet.

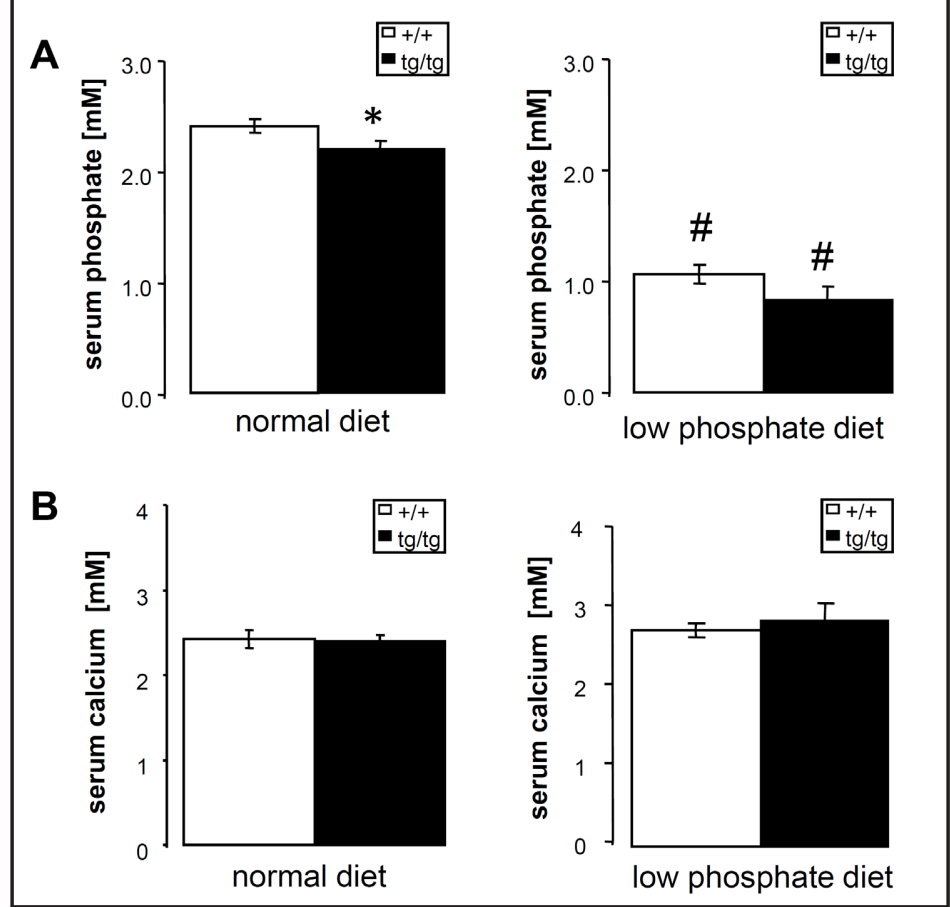

concentration in both, spak ${ }^{\text {tg/tg }}$ mice and in spak ${ }^{w t / w t}$ mice. Under phosphate depleted diet, the serum phosphate concentration remained still lower in $s p a k^{\text {tg/tg }}$ mice than in $s p a k^{w t / w t}$ mice, a difference, however, not reaching statistical significance. Serum $\mathrm{Ca}^{2+}$ concentration was not significantly different between $s p a k^{\text {tg/tg }}$ and $s p a k^{w t / w t}$ mice and was not significantly modified by low phosphate diet.

As phosphaturia could have resulted from altered hormone levels, the serum concentration of parathyroid hormone $(\mathrm{PTH})$, calcitriol $\left(1,25(\mathrm{OH})_{2} \mathrm{D}_{3}\right)$, and fibroblast growth factor 23 (FGF23) were determined. As shown in Fig. 3, the serum concentrations of PTH (Fig. 3A) and of 1,25(OH) $)_{2} \mathrm{D}_{3}$ (Fig. 3B) were similar in spak ${ }^{\text {tg/tg }}$ mice and in spak ${ }^{\omega t / \omega t}$ mice. The serum FGF23 concentration was, however, significantly higher in $s p a k^{\text {tg/tg }}$ mice than in spak $^{\text {wt/wt }}$ mice (Fig. 3C). 


\section{Kidney \\ Blood Pressure \\ Research}

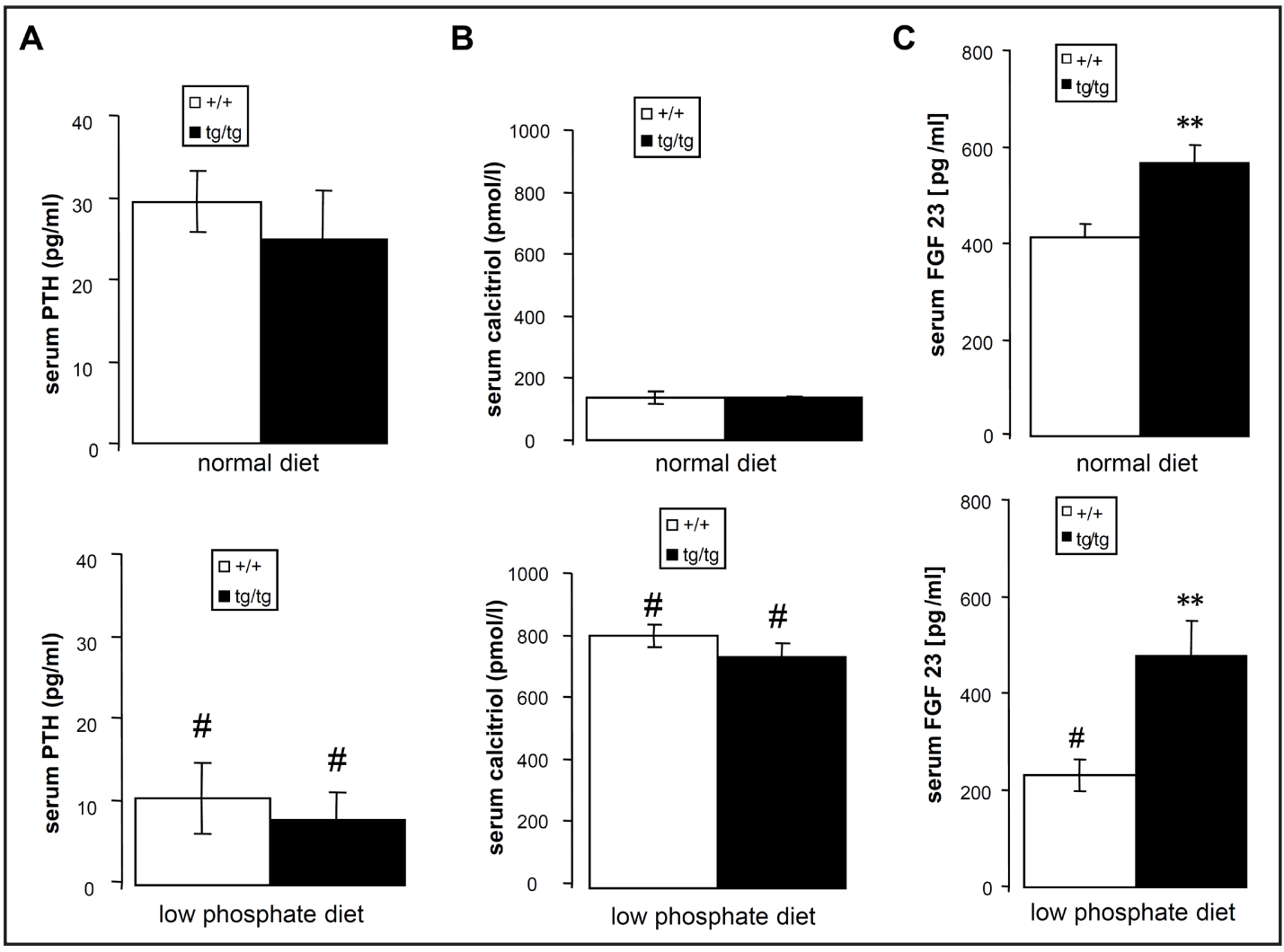

Fig. 3. Serum concentration of $\mathrm{PTH}, 1,25(\mathrm{OH})_{2} \mathrm{D}_{3}$ and FGF23 in $s p a k^{\mathrm{wt} / \mathrm{wt}}$ and spak ${ }^{\mathrm{tg} / \mathrm{tg}}$ mice. Arithmetic means \pm SEM $(n=10-12)$ of serum PTH $(\mathrm{A}), 1,25(\mathrm{OH})_{2} \mathrm{D}_{3}(\mathrm{~B})$, and FGF23 (C) in spak ${ }^{w t / w t}$ mice (white bars) and spak ${ }^{\text {tg/tg }}$ mice (black bars) under normal diet (upper bars) and following dietary phosphate depletion (lower bars). ${ }^{* *}(\mathrm{p}<0.01)$ indicates significant difference from spak ${ }^{w t / w t}$ mice (Student's t-test), \# $(\mathrm{p}<0.05)$ indicates significant difference from control diet.

Dietary phosphate depletion significantly increased $1,25(\mathrm{OH})_{2} \mathrm{D}_{3}$ concentration and significantly decreased serum concentration of PTH in both, $s p a k^{t g / t g}$ and $s p a k^{w t / w t}$ mice. Phosphate depletion decreased serum FGF23 concentrations, an effect reaching statistical significance only in spak ${ }^{w t / w t}$ mice (Fig. 3A-C).

As SPAK stimulates the thiazide sensitive $\mathrm{NaCl}$ cotransporter, additional experiments were performed to elucidate whether thiazide treatment similarly influences FGF23 serum levels. As illustrated in Fig. 4, hydrochlorothiazide treatment was followed by a significant increase of FGF23 serum levels, which was paralleled by phosphaturia and hypophosphatemia, thus mimicking the phenotype of $s p a k^{\text {tg/tg }}$ mice.

Further experiments were performed to elucidate whether the enhanced FGF23 release was paralleled by altered bone density. As shown in Fig. 5, bone density was significantly higher in $s p a k^{t g / t g}$ mice than in spak ${ }^{w t / w t}$ mice.

In order to test, whether Spak is expressed in osteoblasts, mRNA encoding Spak was determined by RT-PCR. As illustrated in Fig. 6, the SPAK transcript was indeed detected in rat osteosarcoma UMR106 cells.

\section{Discussion}

The present observations reveal a completely novel function of WNK/SPAK signaling, i.e. its participation in the regulation of calcium phosphate metabolism and bone density. 


\section{Kidney Blood Pressure Research}

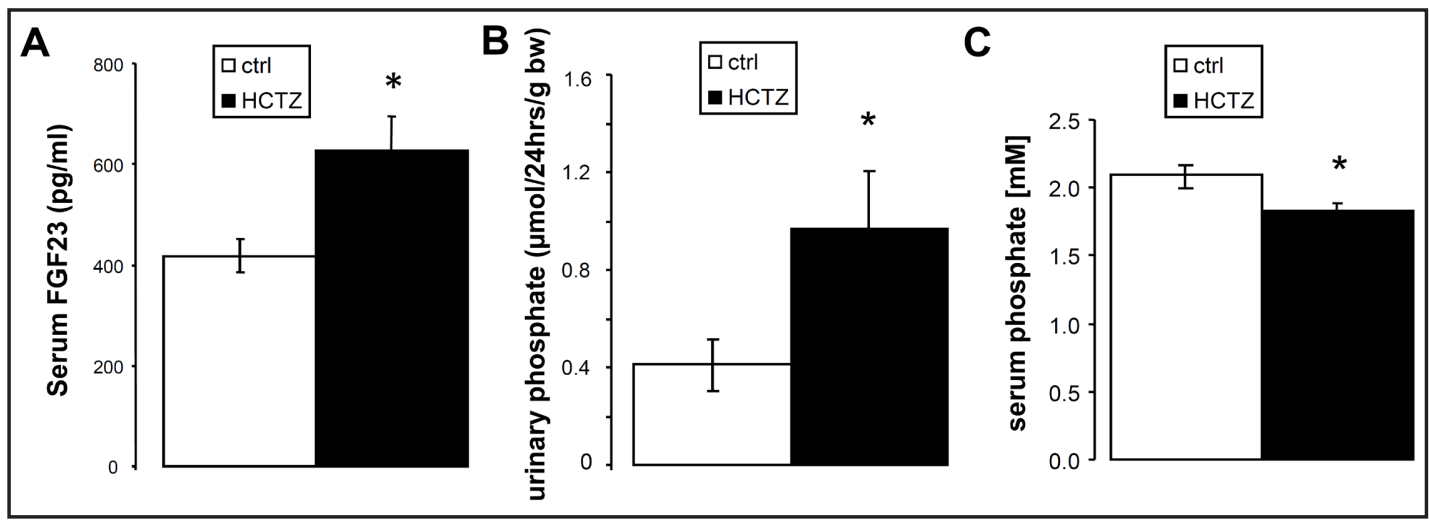

Fig. 4. Effect of hydrochlorothiazide on serum FGF23 levels, urinary phosphate output and serum phosphate concentration in $\operatorname{spak}^{\mathrm{wt} / \mathrm{wt}}$ mice. Arithmetic means \pm SEM $(\mathrm{n}=5)$ of serum FGF23 (A), urinary phosphate excretion (B) and serum phosphate concentration (C) in $s p a k^{w t / w t}$ mice without (white bars) and with (black bars) treament with hydrochlorothiazide. ${ }^{*}(\mathrm{p}<0.05)$ indicates significant difference from untreated $\operatorname{spak}^{w t / w t}$ mice (Student's t-test).

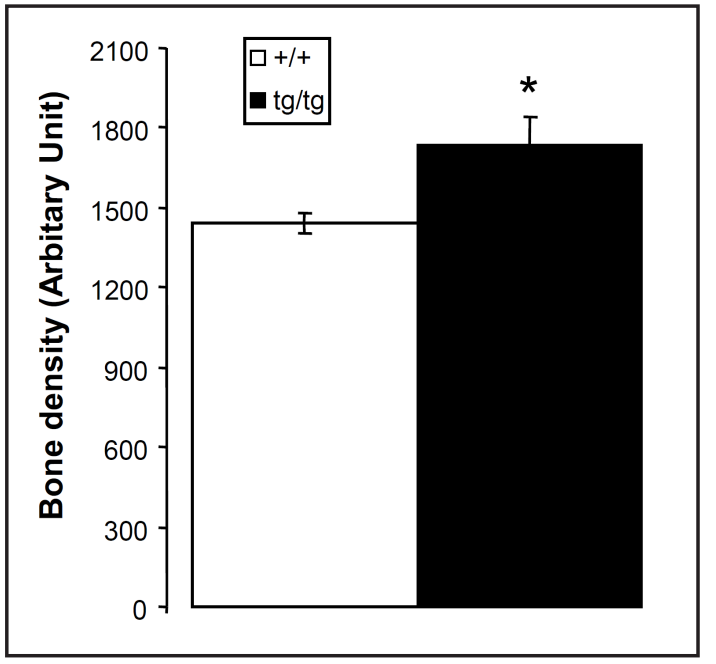

Fig. 5. Bone density in $\operatorname{spak}^{\mathrm{wt} / \mathrm{wt}}$ and $\operatorname{spak}^{\mathrm{tg} / \mathrm{tg}}$ mice. Arithmetic means \pm SEM ( $\mathrm{n}=7$ each group) of bone density in $s p a k^{w t / w t}$ mice (white bars) and spak $^{t g / t g}$ mice (black bars). ${ }^{*} \mathrm{p}<0.05$ vs. respective value of $\operatorname{spak}^{w t / w t}$ mice.

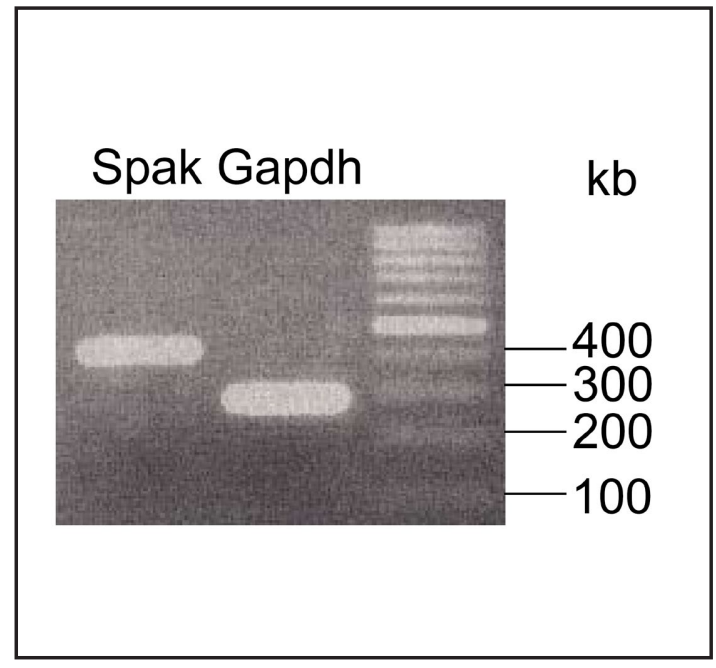

Fig. 6. Spak transcripts in UMR106 cells. Original gel displaying amplified fragments of Spak mRNA (left lane) and Gapdh mRNA (middle lane) from UMR106 cells.

According to the present observations, WNK insensitivity of SPAK decreases urinary $\mathrm{Ca}^{2+}$ excretion, increases bone density, upregulates FGF23 release, and increases urinary phosphate excretion.

The phosphaturia in $s p a k^{t g / t g}$ mice was paralleled by hypophosphatemia and was thus not due to increased serum phosphate concentration. Conversely, the urinary phosphate loss presumably accounts for the hypophosphatemia of the spak $k^{\text {tg/tg }}$ mice. In theory, the phosphaturia of spak ${ }^{t g} / t g$ could have resulted from increased serum levels of PTH, a powerful hormone fostering internalization and degradation of NaPiIIa [34, 38], the most important renal tubular phosphate transporter [45-47]. Thus, PTH leads to phosphaturia and hypophosphatemia [34, 38]. The PTH serum concentration tended, however, to be rather decreased in spak ${ }^{\text {tg/tg }}$ mice. Thus, increased PTH plasma concentrations do presumably not 


\section{Kidney Blood Pressure Research}

Kidney Blood Press Res 2012;36:355-364

\begin{tabular}{l|l}
\hline DOI: $10.1159 / 000343393$ & (c) 2012 S. Karger AG, Basel
\end{tabular}

Published online: December 12, 2012

www.karger.com $/ \mathrm{kbr}$

Pathare/Föller/Michael/Walker/Hierlmeier/Mannheim/Pichler/Lang: SPAK-Sensitive Phosphaturia

contribute to the phosphaturia of spak ${ }^{\text {tg/tg }}$ mice. In theory, phosphaturia may result from altered activity of calcitriol $\left(1,25(\mathrm{OH})_{2} \mathrm{D}_{3}\right)$, which increases plasma phosphate and plasma $\mathrm{Ca}^{2+}$ concentration mainly by stimulating $\mathrm{Ca}^{2+}$ and phosphate absorption in intestine [4851]. Serum $1,25(\mathrm{OH})_{2} \mathrm{D}_{3}$ concentration was, however, not significantly different between spak $^{\text {tg/tg }}$ mice and spak $k^{\text {wt } / \text { wt }}$ mice. The $1,25(\mathrm{OH})_{2} \mathrm{D}_{3}$ serum levels increased following phosphate depletion, which has previously been shown to stimulate renal $1 \alpha$-hydroxylase and thus $1,25(\mathrm{OH})_{2} \mathrm{D}_{3}$ formation [52]. The $1 \alpha$-hydroxylase is further stimulated by PTH [53]. The upregulation of $1,25(\mathrm{OH})_{2} \mathrm{D}_{3}$ during dietary phosphate depletion presumably contributed to the decrease of urinary phosphate output.

The decrease of renal tubular phosphate reabsorption may well have resulted from increased release of FGF23, which is known to decrease renal tubular phosphate transport and plasma phosphate concentration [54]. FGF23 formation is stimulated by $1,25(\mathrm{OH})_{2} \mathrm{D}_{3}$ and FGF23 in turn decreases the formation of 1,25(OH)2 $\mathrm{D}_{3}[55,56]$. FGF23 formation is further stimulated by PTH, increased phosphate intake and hyperphosphatemia [57-59]. Accordingly, phosphate deficient diet decreased serum FGF23 levels. However, the enhanced FGF23 serum level of $s p a k^{\text {tg/tg }}$ mice cannot be explained by PTH or hypophosphatemia. In theory, SPAK may influence FGF23 release from osteoblasts indirectly, by stimulating the $\mathrm{NaCl}$ cotransporter NCC. Along those lines, hydrochlorothiazide indeed increased FGF23 release, an effect paralleled by phosphaturia and hypophosphatemia. Thus, inhibition of NCC mimics the phenotype of $s p a k^{\text {tg/tg }}$ mice. Along those lines, NCC activity plays a pivotal role for bone differentiation and bone mineralisation [27]. The present observations do, however, not allow discriminating, whether the effect of hydrochlorothiazide on FGF23 plasma concentration was secondary to inhibition of NCC in kidney or in bone.

The phosphaturia of $s p a k^{\text {tg/tg }}$ mice is paralleled by anticalciuria, which may again be an indirect effect of impaired $\mathrm{NaCl}$ cotransporter activity. In view of the present observations it is tempting to speculate that the phosphaturia is the result of the following sequence of events: Lack of renal tubular SPAK activity decreases the activity of the $\mathrm{NaCl}$ cotransporter in early distal tubule. The volume depletion triggers a compensatory increase of $\mathrm{NaCl}$ reabsorption in proximal renal tubules and Henle's Loop. The enhanced proximal tubular and loop $\mathrm{Na}^{+}$reabsorption is paralleled by a similar increase of $\mathrm{Ca}^{2+}$ reabsorption resulting in anticalciuria. The renal $\mathrm{Ca}^{2+}$ retention enhances bone mineralization, which triggers FGF23 release. The enhanced FGF23 levels cause phosphaturia. Along those lines, inhibition of the $\mathrm{NaCl}$ cotransporter with hydrochlorothiazide similarly leads to anticalciuria, an effect again at least partially explained by compensatory increase of proximal tubular $\mathrm{Na}^{+}$reabsorption with parallel increase of renal tubular $\mathrm{Ca}^{2+}$ reabsorption [26]. The rather constant plasma concentration of $\mathrm{Ca}^{2+}$ does not support the assumption that $\mathrm{Ca}^{2+}$ retention drives enhanced bone mineralisation in $\operatorname{spak}^{\text {tg/tg }}$ mice. It should be kept in mind, though, that it is the free ionized $\mathrm{Ca}^{2+}$ rather than total $\mathrm{Ca}^{2+}$, which is relevant for bone mineralisation. The hypophosphatemia decreases complexation of $\mathrm{Ca}^{2+}$ by phosphate and the free $\mathrm{Ca}^{2+}$ concentration may, at least in theory, be indeed (slightly) higher in $s p a k^{\text {tg/tg }}$ mice and $s p a k^{w t / w t}$ mice.

\section{Conclusion}

WNK/SPAK signaling participates in the regulation of FGF23 release as well as renal tubular $\mathrm{Ca}^{2+}$ and phosphate transport. WNK resistance of SPAK activity leads to increased FGF23 release, anticalciuria, phosphaturia, hypophosphatemia and enhanced bone density. The present observations thus disclose a novel, powerful mechanism contributing to the regulation of mineral metabolism and a novel functional role of WNK/SPAK signaling.

\section{Conflict of Interests}

The authors declare that they have no competing financial interests to disclose. 


\section{Kidney \\ Blood Pressure Research}

\section{Acknowledgements}

The authors are indebted to Dario Alessi from the MRC Protein Phosphorylation Unit, College of Life Sciences, University of Dundee, Dundee, who kindly provided mice and the SPAK antibody. The authors are grateful to Maren Koenig for data acquisition and to Martin S. Judenhofer for valuable discussions. The authors further gratefully acknowledge the meticulous preparation of the manuscript by L. Subasic and M. Petrea. This work was supported by the Deutsche Forschungsgemeinschaft DFG.

\section{References}

1 Rafiqi FH, Zuber AM, Glover M, Richardson C, Fleming S, Jovanovic S, Jovanovic A, O'Shaughnessy KM, Alessi DR: Role of the WNK-activated SPAK kinase in regulating blood pressure. EMBO Mol Med 2010;2:63-75.

-2 Yang SS, Lo YF, Wu CC, Lin SW, Yeh CJ, Chu P, Sytwu HK, Uchida S, Sasaki S, Lin SH: SPAK-knockout mice manifest Gitelman syndrome and impaired vasoconstriction. J Am Soc Nephrol 2010;21:1868-1877.

-3 Castaneda-Bueno M, Gamba G: SPAKling insight into blood pressure regulation. EMBO Mol Med 2010;2:39-41.

4 Vitari AC, Deak M, Morrice NA, Alessi DR: The WNK1 and WNK4 protein kinases that are mutated in Gordon's hypertension syndrome phosphorylate and activate SPAK and OSR1 protein kinases. Biochem J 2005;391:17-

24.

5 Vitari AC, Thastrup J, Rafiqi FH, Deak M, Morrice NA, Karlsson HK, Alessi DR: Functional interactions of the SPAK/OSR1 kinases with their upstream activator WNK1 and downstream substrate NKCC1. Biochem J 2006;397:223-231.

6 Glover M, Zuber AM, O'Shaughnessy KM: Hypertension, dietary salt intake, and the role of the thiazide-sensitive sodium chloride transporter NCCT. Cardiovasc Ther 2011;29:68-76.

-7 Kahle KT, Rinehart J, Lifton RP: Phosphoregulation of the Na-K-2Cl and K-Cl cotransporters by the WNK kinases. Biochim Biophys Acta 2010;1802:1150-1158.

-8 O'Reilly M, Marshall E, Speirs HJ, Brown RW: WNK1, a gene within a novel blood pressure control pathway, tissue-specifically generates radically different isoforms with and without a kinase domain. J Am Soc Nephrol 2003;14:2447-2456.

-9 Flatman PW: Cotransporters, WNKs and hypertension: an update. Curr Opin Nephrol Hypertens 2008;17:186192.

10 Furgeson SB, Linas S: Mechanisms of type I and type II pseudohypoaldosteronism. J Am Soc Nephrol 2010;21:1842-1845.

11 Uchida S: Pathophysiological roles of WNK kinases in the kidney. Pflugers Arch 2010;460:695-702.

-12 Wilson FH, Disse-Nicodeme S, Choate KA, Ishikawa K, Nelson-Williams C, Desitter I, Gunel M, Milford DV, Lipkin GW, Achard JM, Feely MP, Dussol B, Berland Y, Unwin RJ, Mayan H, Simon DB, Farfel Z, Jeunemaitre X, Lifton RP: Human hypertension caused by mutations in WNK kinases. Science 2001;293:1107-1112.

-13 Achard JM, Disse-Nicodeme S, Fiquet-Kempf B, Jeunemaitre X: Phenotypic and genetic heterogeneity of familial hyperkalaemic hypertension (Gordon syndrome). Clin Exp Pharmacol Physiol 2001;28:1048-1052.

14 Capasso G, Cantone A, Evangelista C, Zacchia M, Trepiccione F, Acone D, Rizzo M: Channels, carriers, and pumps in the pathogenesis of sodium-sensitive hypertension. Semin Nephrol 2005;25:419-424.

15 Richardson C, Sakamoto K, de los HP, Deak M, Campbell DG, Prescott AR, Alessi DR: Regulation of the NKCC2 ion cotransporter by SPAK-OSR1-dependent and -independent pathways. J Cell Sci 2011;124:789-800.

16 Delpire E, Gagnon KB: SPAK and OSR1, key kinases involved in the regulation of chloride transport. Acta Physiol (Oxf) 2006;187:103-113.

17 Delpire E, Gagnon KB: SPAK and OSR1: STE20 kinases involved in the regulation of ion homoeostasis and volume control in mammalian cells. Biochem J 2008;409:321-331.

18 Gimenez I: Molecular mechanisms and regulation of furosemide-sensitive Na-K-Cl cotransporters. Curr Opin Nephrol Hypertens 2006;15:517-523.

19 Huang CL, Yang SS, Lin SH: Mechanism of regulation of renal ion transport by WNK kinases. Curr Opin Nephrol Hypertens 2008;17:519-525. 


\section{Kidney \\ Blood Pressure Research}

Kidney Blood Press Res 2012;36:355-364

\begin{tabular}{l|l}
\hline DOI: $10.1159 / 000343393$ & C 2012 S. Karger AG, Basel
\end{tabular}

Published online: December 12, 2012

www.karger.com/kbr

Pathare/Föller/Michael/Walker/Hierlmeier/Mannheim/Pichler/Lang: SPAK-Sensitive Phosphaturia

20 Richardson C, Alessi DR: The regulation of salt transport and blood pressure by the WNK-SPAK/OSR1 signalling pathway. J Cell Sci 2008;121:3293-3304.

21 Gagnon KB, Delpire E: On the substrate recognition and negative regulation of SPAK, a kinase modulating Na+K+-2Cl- cotransport activity. Am J Physiol Cell Physiol 2010;299:C614-C620.

22 Mercier-Zuber A, O'Shaughnessy KM: Role of SPAK and OSR1 signalling in the regulation of NaCl cotransporters. Curr Opin Nephrol Hypertens 2011;20:534-540.

-23 Glover M, O'Shaughnessy KM: SPAK and WNK kinases: a new target for blood pressure treatment? Curr Opin Nephrol Hypertens 2011;20:16-22.

-24 Lin SH, Yu IS, Jiang ST, Lin SW, Chu P, Chen A, Sytwu HK, Sohara E, Uchida S, Sasaki S, Yang SS: Impaired phosphorylation of $\mathrm{Na}+\mathrm{K}+-2 \mathrm{Cl}$ - cotransporter by oxidative stress-responsive kinase-1 deficiency manifests hypotension and Bartter-like syndrome. Proc Natl Acad Sci U S A 2011;108:17538-17543.

-25 Villa F, Deak M, Alessi DR, van Aalten DM: Structure of the OSR1 kinase, a hypertension drug target. Proteins 2008;73:1082-1087.

-26 Nijenhuis T, Vallon V, van der Kemp AW, Loffing J, Hoenderop JG, Bindels RJ: Enhanced passive Ca2+ reabsorption and reduced Mg2+ channel abundance explains thiazide-induced hypocalciuria and hypomagnesemia. J Clin Invest 2005;115:1651-1658.

27 Dvorak MM, De Joussineau C, Carter DH, Pisitkun T, Knepper MA, Gamba G, Kemp PJ, Riccardi D: Thiazide diuretics directly induce osteoblast differentiation and mineralized nodule formation by interacting with a sodium chloride co-transporter in bone. J Am Soc Nephrol 2007;18:2509-2516.

28 Nicolet-Barousse L, Blanchard A, Roux C, Pietri L, Bloch-Faure M, Kolta S, Chappard C, Geoffroy V, Morieux C, Jeunemaitre X, Shull GE, Meneton P, Paillard M, Houillier P, De Vernejoul MC: Inactivation of the Na-Cl cotransporter (NCC) gene is associated with high BMD through both renal and bone mechanisms: analysis of patients with Gitelman syndrome and Ncc null mice. J Bone Miner Res 2005;20:799-808.

29 Mendes AI, Mascarenhas MR, Matos S, Sousa I, Ferreira J, Barbosa AP, Bicho M, Jordan P: A WNK4 gene variant relates to osteoporosis and not to hypertension in the Portuguese population. Mol Genet Metab 2011;102:465469.

-30 Allon M: Effects of insulin and glucose on renal phosphate reabsorption: interactions with dietary phosphate. J Am Soc Nephrol 1992;2:1593-1600.

-31 DeFronzo RA, Goldberg M, Agus ZS: The effects of glucose and insulin on renal electrolyte transport. J Clin Invest 1976;58:83-90.

-32 Feld S, Hirschberg R: Insulinlike growth factor I and the kidney. Trends Endocrinol Metab 1996;7:85-93.

-33 Jehle AW, Forgo J, Biber J, Lederer E, Krapf R, Murer H: IGF-I and vanadate stimulate Na/Pi-cotransport in OK cells by increasing type II Na/Pi-cotransporter protein stability. Pflugers Arch 1998;437:149-154.

34 Murer H, Hernando N, Forster I, Biber J: Proximal tubular phosphate reabsorption: molecular mechanisms. Physiol Rev 2000;80:1373-1409.

- 35 Nowik M, Picard N, Stange G, Capuano P, Tenenhouse HS, Biber J, Murer H, Wagner CA: Renal phosphaturia during metabolic acidosis revisited: molecular mechanisms for decreased renal phosphate reabsorption. Pflugers Arch 2008;457:539-549.

-36 Picard N, Capuano P, Stange G, Mihailova M, Kaissling B, Murer H, Biber J, Wagner CA: Acute parathyroid hormone differentially regulates renal brush border membrane phosphate cotransporters. Pflugers Arch 2010;460:677-687.

-37 Bacic D, Schulz N, Biber J, Kaissling B, Murer H, Wagner CA: Involvement of the MAPK-kinase pathway in the PTH-mediated regulation of the proximal tubule type IIa Na+/Pi cotransporter in mouse kidney. Pflugers Arch 2003;446:52-60.

38 Bacic D, Lehir M, Biber J, Kaissling B, Murer H, Wagner CA: The renal Na+/phosphate cotransporter NaPi-IIa is internalized via the receptor-mediated endocytic route in response to parathyroid hormone. Kidney Int 2006;69:495-503.

39 Bhandaru M, Kempe DS, Rotte A, Capuano P, Pathare G, Sopjani M, Alesutan I, Tyan L, Huang DY, Siraskar B, Judenhofer MS, Stange G, Pichler BJ, Biber J, Quintanilla-Martinez L, Wagner CA, Pearce D, Foller M, Lang F: Decreased bone density and increased phosphaturia in gene-targeted mice lacking functional serum- and glucocorticoid-inducible kinase 3. Kidney Int 2011;80:61-67.

40 Dermaku-Sopjani M, Sopjani M, Saxena A, Shojaiefard M, Bogatikov E, Alesutan I, Eichenmuller M, Lang F: Downregulation of NaPi-IIa and NaPi-IIb Na-coupled phosphate transporters by coexpression of Klotho. Cell Physiol Biochem 2011;28:251-258. 


\section{Kidney \\ Blood Pressure Research}

Kidney Blood Press Res 2012;36:355-364

\begin{tabular}{l|l}
\hline DOI: $10.1159 / 000343393$ & (C) 2012 S. Karger AG, Basel
\end{tabular}

Published online: December 12, 2012

www.karger.com/kbr

Pathare/Föller/Michael/Walker/Hierlmeier/Mannheim/Pichler/Lang: SPAK-Sensitive Phosphaturia

41 Foller M, Kempe DS, Boini KM, Pathare G, Siraskar B, Capuano P, Alesutan I, Sopjani M, Stange G, Mohebbi N, Bhandaru M, Ackermann TF, Judenhofer MS, Pichler BJ, Biber J, Wagner CA, Lang F: PKB/SGK-resistant GSK3 enhances phosphaturia and calciuria. J Am Soc Nephrol 2011;22:873-880.

42 Hu MC, Shi M, Zhang J, Pastor J, Nakatani T, Lanske B, Razzaque MS, Rosenblatt KP, Baum MG, Kuro-o M, Moe OW: Klotho: a novel phosphaturic substance acting as an autocrine enzyme in the renal proximal tubule. FASEB J 2010;24:3438-3450.

43 Kempe DS, Dermaku-Sopjani M, Frohlich H, Sopjani M, Umbach A, Puchchakayala G, Capasso A, Weiss F, Stubs M, Foller M, Lang F: Rapamycin-induced phosphaturia. Nephrol Dial Transplant 2010;25:2938-2944.

-44 Kempe DS, Ackermann TF, Boini KM, Klaus F, Umbach AT, Dermaku-Sopjani M, Judenhofer MS, Pichler BJ, Capuano P, Stange G, Wagner CA, Birnbaum MJ, Pearce D, Foller M, Lang F: Akt2/PKBbeta-sensitive regulation of renal phosphate transport. Acta Physiol (Oxf) 2010;200:75-85.

-45 Biber J, Hernando N, Forster I, Murer H: Regulation of phosphate transport in proximal tubules. Pflugers Arch 2009;458:39-52.

46 Murer H, Forster I, Biber J: The sodium phosphate cotransporter family SLC34. Pflugers Arch 2004;447:763767.

47 Villa-Bellosta R, Ravera S, Sorribas V, Stange G, Levi M, Murer H, Biber J, Forster IC: The Na+-Pi cotransporter PiT-2 (SLC20A2) is expressed in the apical membrane of rat renal proximal tubules and regulated by dietary Pi. Am J Physiol Renal Physiol 2009;296:F691-F699.

-48 Cross HS, Debiec H, Peterlik M: Mechanism and regulation of intestinal phosphate absorption. Miner Electrolyte Metab 1990;16:115-124.

-49 Khanal RC, Nemere I: Regulation of intestinal calcium transport. Annu Rev Nutr 2008;28:179-196.

50 Ko SH, Choi KC, Oh GT, Jeung EB: Effect of dietary calcium and 1,25-(OH)2D3 on the expression of calcium transport genes in calbindin-D9k and -D28k double knockout mice. Biochem Biophys Res Commun 2009;379:227-232.

-51 Sterling TM, Nemere I: 1,25-dihydroxyvitamin D3 stimulates vesicular transport within $5 \mathrm{~s}$ in polarized intestinal epithelial cells. J Endocrinol 2005;185:81-91.

52 Perwad F, Azam N, Zhang MY, Yamashita T, Tenenhouse HS, Portale AA: Dietary and serum phosphorus regulate fibroblast growth factor 23 expression and 1,25-dihydroxyvitamin D metabolism in mice. Endocrinology 2005;146:5358-5364.

53 Portale AA, Miller WL: Human 25-hydroxyvitamin D-1alpha-hydroxylase: cloning, mutations, and gene expression. Pediatr Nephrol 2000;14:620-625.

54 Amatschek S, Haller M, Oberbauer R: Renal phosphate handling in human--what can we learn from hereditary hypophosphataemias? Eur J Clin Invest 2010;40:552-560.

55 Razzaque MS, Lanske B: The emerging role of the fibroblast growth factor-23-klotho axis in renal regulation of phosphate homeostasis. J Endocrinol 2007;194:1-10.

-56 Tang WJ, Wang LF, Xu XY, Zhou Y, Jin WF, Wang HF, Gao J: Autocrine/paracrine action of vitamin D on FGF23 expression in cultured rat osteoblasts. Calcif Tissue Int 2010;86:404-410.

57 Lavi-Moshayoff V, Wasserman G, Meir T, Silver J, Naveh-Many T: PTH increases FGF23 gene expression and mediates the high-FGF23 levels of experimental kidney failure: a bone parathyroid feedback loop. Am J Physiol Renal Physiol 2010;299:F882-F889.

-58 Vervloet MG, van Ittersum FJ, Buttler RM, Heijboer AC, Blankenstein MA, ter Wee PM: Effects of dietary phosphate and calcium intake on fibroblast growth factor-23. Clin J Am Soc Nephrol 2011;6:383-389.

59 Wolf M: Forging forward with 10 burning questions on FGF23 in kidney disease. J Am Soc Nephrol 2010;21:1427-1435. 